\title{
Isabelle Attané and Jacques Véron (eds.): Gender Discriminations Among Young Children in Asia.
}

Pondicherry: French Institute of Pondicherry, 2005, 314 pp.

\section{Marina Thorborg}

\section{OpenEdition}

\section{Journals}

Édition électronique

URL : http://journals.openedition.org/chinaperspectives/1053

DOI : 10.4000/chinaperspectives.1053

ISSN : 1996-4617

\section{Éditeur}

Centre d'étude français sur la Chine contemporaine

Édition imprimée

Date de publication : 1 octobre 2006

ISSN : 2070-3449

\section{Référence électronique}

Marina Thorborg, «Isabelle Attané and Jacques Véron (eds.): Gender Discriminations Among Young

Children in Asia. », China Perspectives [En ligne], 67 | september-october 2006, mis en ligne le 01 juin 2007, consulté le 22 septembre 2020. URL : http://journals.openedition.org/chinaperspectives/1053 DOI : https://doi.org/10.4000/chinaperspectives.1053

Ce document a été généré automatiquement le 22 septembre 2020

(c) All rights reserved 


\section{Isabelle Attané and Jacques Véron (eds.): Gender Discriminations Among Young Children in Asia.}

Pondicherry: French Institute of Pondicherry, 2005, 314 pp.

Marina Thorborg

1 Since the alarm signal was first sounded by professor Amartya Sen in $1990^{1}$ works have appeared on the growing imbalances between the sexes in East and South Asia, asking the questions why, where, and who. ${ }^{2}$

However, this timely collection of solid research by specialists-half of them demographers-as well considers how to remedy this disquieting situation.

This anthology is the result of a seminar by the French Institute in Pondicherry in collaboration the French Centre for Population and Development, the Indian UNDPA, and the National Institute for Demographic Studies in Paris. Historically China and parts of India have been characterised by high sex ratios, but so have other societies during different epochs. ${ }^{3}$ Major changes occurred with the introduction of modern scanning technology in the 1980s showing the sex of the foetus. Then sex ratios at birth became even more unfavourable towards girls mainly in highly patriarchal East and South Asia, but not in South East Asia, ${ }^{4}$ where both parents were of equal importance, care in old age was preferred to be by daughters, marriage and inheritance customs were far less discriminating towards women giving them more space in society and labour. ${ }^{5}$

4 This anthology focuses mainly on India and China, each displaying patterns of discrimination expressed in sex ratios at birth, infant mortality by sex, and life expectancy by sex all showing - when compared to the international norm-women at a disadvantage. ${ }^{6}$ In India massive sex discrimination is regionally concentrated in the northwest part already documented by the British in the nineteenth century for its lack of women and high rate of violent crime. ${ }^{7}$ Roy Choudhury discusses in-depth the development of provincial imbalances revealed in the census of 2001 showing that the low desirability of girl children is not mitigated by affluence. The more girls already 
born to a family the more skewed the sex ratios. In addition urbanisation is associated with smaller families whereby pre-natal scanning is used to assure at least one son. Exactly the same phenomena have been observed in China. However, in China, the more Han Chinese in an area the greater the distortions in sex ratios. This is shown in an interesting chapter by Christophe Guilmoto, employing a spatial pattern of analysing both India and China, though failing to mention that the national minorities were allowed to have more children and that in mixed marriages more couples were choosing minority status for that very reason which could have explained some of the differences.

5 Irudaya Rajan and S. Sudha make a stimulating in-depth analysis of the persistent daughter disadvantage in India, showing together with China the greatest sex differences in Asia in literacy and education with repercussions for women on the labour market. They question the viability of deeply entrenched notions such as why women always should marry and marry older men. However, some mishaps occurred in this chapter with the references going only to the letter " $K$ " and figures $1 \mathrm{a}, 1 \mathrm{~b}, 2 \mathrm{a}$, and $2 \mathrm{~b}$ missing. In the chapter "Does Gender Make a Difference", Lin Tang and Yueping Song show how to practically lessen gender discrimination in school books in China and give a constructive six-point strategy for improvement while citing research showing that teaching materials for primary schools still show women as "wife, mother, teacher and nurse" while men are characterised as leaders and creators of wealth. Sometimes quoted Chinese sources contradict themselves, i.e. on page 212, claiming firstly that all females and males under 50 have more than nine years education and secondly that $82.5 \%$ of all rural women and $67.7 \%$ of rural men do not. Considering that $60 \%$ of the Chinese are still rural residents and the proportion of aged fifty and over in the population, one of these statements is grossly exaggerated.

6 Returning to India two well-written chapters deal with regional development; one by Stéphanie Vella and Sébastien Oliveau entitled "Spatio-temporal Trends of Female Discrimination in Tamil Nadu", and another, entitled "Child Sex Ratio Imbalance in North-West India, Haryana and Punjab," by Aswini Nanda and Jacques Véron. Vella and Oliveau make a fascinating analysis delineating in detail the multiple factors behind the spread of infanticide and changed marriage patterns-from consanguineous to hypergamic - and with that the adoption of a dowry by a dominant agricultural caste and how therefore land-owning families began discriminating against their girls earlier than the landless. Nanda and Véron demonstrate clearly in their thought-provoking paper how "modernity"-being urban, more affluent and educated-combined with "backwardness"-the necessity of a son and accepting escalating dowry costs-increased gender discrimination leading to fewer children and even fewer girls in two of the most developed states in India. Isabelle Attané shows similar trends in a most interesting chapter on "Gender Discrimination in Early Stages of Life in China," also clearly proving that under-enumeration accounts for less than $10 \%$ of girls missing in China.

7 In a highly analytical paper entitled "Improving Girl Child Survival," Li Shuzhuo and Zhu Chuzhu scrutinise co-operation projects intended to weaken the mortal combination of the patriarchal kinship system, son preference, and birth control, and how to reverse the trend by promoting women's greater economic independence and enhanced self-awareness. A fine paper entitled "Taiwan and Child Well-being," by Wen Shang Yang and Likwang Chen, shows new trends of thinking stressing quality in 
children instead of quantity. A further thought-provoking paper, this time on South Korea, by Doo-sub Kim on changing trends, shows that the increasingly distorted sex ratio peaked in 1995 because of fast-changing values among the younger generation partly because of governments campaigns. In South Korea neither infanticide nor neglect of girl children were prominent. A totally different and interesting paper on son preference in Pakistan by Karim Mehtab depicts a society prior to any fertility transition, hence without killing of baby girls or foetal scanning, with women having children until the desired number of sons are produced, hence high maternal mortality. However, better care of sons has led to a more rapid decrease in male infant mortality. Would these phenomena explain a surplus of 6.5 million men according to the latest Pakistani statistics, and that $9 \%$ of the female population is missing, as in India and Taiwan, but lower than in China? ${ }^{8}$

8 This anthology is recommended for scholars and laypeople alike offering not only fascinating and penetrating analysis but also showing what has worked, how trends have turned and why.

\section{NOTES}

1. Amartya Sen, "More Than 100 Million Women Are Missing", The New York Review, December $20^{\text {th }} 1990$.

2. For recent references see footnotes to article by Marina Thorborg, "Where Have all the Young Girls Gone, Chinese Fatal Daughter Discrimination-A Regional Comparison" , in China Perspectives, Hong Kong, no 86 in French February, 2005, and No. 57 in English, January-February, 2005.

3. Valerie M. Hudson and Andrea M. den Boer, Bare Branches Security Implications of Asia's Surplus Male Population, MIT Press, London, 2004.

4. M. Thorborg, 2005.

5. Lela Dube, Structures and Strategies Women Work and Family in Asia, Sage Publication, 1990.

6. $\mathrm{N}: \mathrm{B}$ : In the last sentence of the introduction the figures of the international norm have been mixed up. This should be 105 males per 100 females, p.19.

7. V. Hudson and A, Boer, 2004.

8. M. Thorborg, 2005. 